Tropical Journal of Pharmaceutical Research August 2012; 11 (4): 605-610

(c) Pharmacotherapy Group,

Faculty of Pharmacy, University of Benin

Benin City, 300001 Nigeria.

All rights reserved.

Available online at http://www.tjpr.org

Research Article

http://dx.doi.org/10.4314/tjpr.v11i4.11

\title{
Antinociceptive Activity of Thymoquinone and its Structural Analogues: A Structure-Activity Relationship Study
}

\author{
Damião $P$ de Sousa ${ }^{1 *}$, Franklin FF Nóbrega ${ }^{2}$, Camila CMP Santos ${ }^{2}$, \\ Rubens B Benedito ${ }^{2}$, Ygor W Vieira ${ }^{3}$, Marciana P Uliana ${ }^{3}$, Timothy J \\ Brocksom ${ }^{3}$ and Reinaldo $\mathrm{N}$ de Almeida ${ }^{2}$ \\ ${ }^{1}$ Laboratório de Química de Produtos Naturais e Sintéticos Bioativos (LAPROBIO), Departamento de Fisiologia, \\ Universidade Federal de Sergipe, CEP 49100-000, São Cristóvão, Sergipe, '2Laboratório de Tecnologia \\ Farmacêutica/Universidade Federal da Paraíba, Caixa Postal 5009, CEP 58051-970, João Pessoa, Paraíba, \\ ${ }^{3}$ Laboratório de Química Bio-Orgânica, Departamento de Química, Universidade Federal de São Carlos, Caixa \\ Postal 676, 13565-905 São Carlos, SP, Brazil.
}

\begin{abstract}
Purpose: To investigate the structural features that influence the antinociceptive activity of thymoquinone and their structural analogues.

Methods: The quinones were prepared by an oxidation procedure using molecular oxygen and catalysis with [Co"(salen)] from the respective phenols. The antinociceptive activity of para-benzoquinones (10 $\mathrm{mg} / \mathrm{kg}$, ip) was evaluated using formalin test in mice. Vehicle (5\% Tween 80) or morphine (10 mg/kg) were used as control group and standard drug, respectively. The amount of time spent licking the injected paw was considered as the nociceptive response.

Results: Among the compounds tested, five para-benzoquinones showed antinociceptive activity. The 2-isopropyl-para-benzoquinone presented the highest potency in first and second phases and produced a near-maximal inhibition $(p<0.001)$ in the formalin test, similar to morphine $(p<0.001)$.

Conclusion: Our experimental results show that by appropriate structural modification of parabenzoquinones it may be possible to develop novel analgesic drugs.
\end{abstract}

Keywords: Quinones, Antinociceptive activity, Analgesic, Central nervous system, Structure-activity relationship, Medicinal plant.

*Corresponding author: Email: damiao_desousa@yahoo.com.br 
de Sousa et al

\section{INTRODUCTION}

Although a considerable number of analgesic drugs are available for the treatment of pain, medicinal plants are widely investigated as a rich source of natural components capable of exerting peripheral and central analgesic activity, but with the potential to be devoid of undesirable side effects and addictive properties displayed by conventional analgesic drugs. Furthermore, some chemical constituents of medicinal plants are candidates for analgesic drugs $[1,2]$.

Para-benzoquinones are potentially derivable by oxidation of suitable phenolic compounds. Many of these para-benzoquinones have important biochemical functions in electron transport systems for respiration or photosynthesis. Natural products containing the para-benzoquinone sub-structural unit are many, for example, vitamins $\mathrm{K}_{1}$ and $\mathrm{K}_{2}$, coenzyme $Q$ (ubiquinone), and also occur in many terpenes [3].

The pharmacological properties attributed to naturally occurring quinones are thus well established. For example, thymoquinone, the principal active constituent of Nigella sativa seeds, presents antinociceptive activity [4]. Therefore, these facts led us to compare the antinociceptive activity of six structurallyrelated para-benzoquinones prepared via oxidation reactions.

\section{EXPERIMENTAL}

Solvents and reagents were used as received from the manufacturer, or purified, when required, by standard procedures. The six phenols and N,N'-bis(salicylidene) ethylenediaminocobalt(II)[Co"(salen)] employed were commercially available products (Aldrich) and used as obtained

\section{General procedure for metal complex- catalyzed oxidation}

Phenol (1.0 mmol) was dissolved in dimethylformamide (DMF, $5 \mathrm{~mL}$ ) and oxygen was bubbled into the reaction mixture for a few minutes by way of a rubber septum and a syringe needle, and then an oxygen atmosphere was maintained with a balloon by filling a toy balloon, and coupling to the same syringe inlet. Co" (salen) catalyst $(0.0195 \mathrm{~g}$, $0.06 \mathrm{mmol}$ ) was added, and the reaction mixture stirred at room temperature for $3 \mathrm{~h}$. More of the catalyst $(0.0195 \mathrm{~g}, 0.06 \mathrm{mmol})$ was added and the reaction mixture stirred for another $3 \mathrm{~h}$ at room temperature. The process was repeated once more, for a total addition of $0.18 \mathrm{mmol}(0.0585 \mathrm{~g})$ catalyst and a total reaction time of $24 \mathrm{~h}$. Ether $(20 \mathrm{~mL})$ was added and the black mixture washed with $0.1 \mathrm{~mol} \cdot \mathrm{L}^{-1} \mathrm{HCl}(2 \times 10 \mathrm{~mL})$, water and brine. The ethereal solution was dried over anhydrous magnesium sulfate $\left(\mathrm{MgSO}_{4}\right)$ and the solvent evaporated. The residue was purified by sublimation (or by flash column chromatography when necessary, using as eluent a mixture of 9:1 hexane:ethyl acetate) $[5,6]$.

\section{Nuclear Magnetic Resonance (NMR) and melting point determinations}

${ }^{1} \mathrm{H}$ and ${ }^{13} \mathrm{C}$ NMR spectra were obtained on a Bruker DRX-400 NMR spectrometer at 400 and $100 \mathrm{MHz}$ respectively. Chemical shifts were expressed in ppm downfield from a tetramethylsilane internal standard. Melting point was determined on a Micro Química apparatus (model APF 301) and are uncorrected.

\section{Animals}

Male Swiss mice $(28-34 \mathrm{~g})$ were obtained from the vivarium Prof. Dr. ThomasGeorge of LTF/UFPB, in which they were created. The animals were maintained at constant room temperature $\left(23 \pm 1{ }^{\circ} \mathrm{C}\right)$ and on a $12 / 12 \mathrm{~h}$ light-dark cycle (light from 06:00 to 18:00), with free access to food and water. All behavioral observations were conducted between 08:00 and 12:00 $\mathrm{h}$ and the study was approved by the Ethics Committee for the Care and Use of Animals of the Federal University of Paraiba (Comitê de Ética em 
Pesquisa Animal do Laboratório de Tecnologia Farmacêutica - CEPA № 0202/08) [7].

\section{Formalin test}

The animals received an injection of $20 \mu \mathrm{l}$ of $2.5 \%$ formalin $(0.92 \%$ formaldehyde diluted in normal saline) in the subplantar area of the right hind paw. The duration of paw licking was measured in the periods 1 - 5 min (first phase) and 15 - 30 min (second phase) after the formalin injection. The amount of time spent licking the injected paw was considered as the nociceptive response. Animals were divided into eight groups $(n=8)$ and subjected to intraperitoneal (ip) administration of para-benzoquinones $1-6$ (10 $\mathrm{mg} / \mathrm{kg}$, ip), vehicle $(5 \%$ Tween 80$)$ or morphine (10

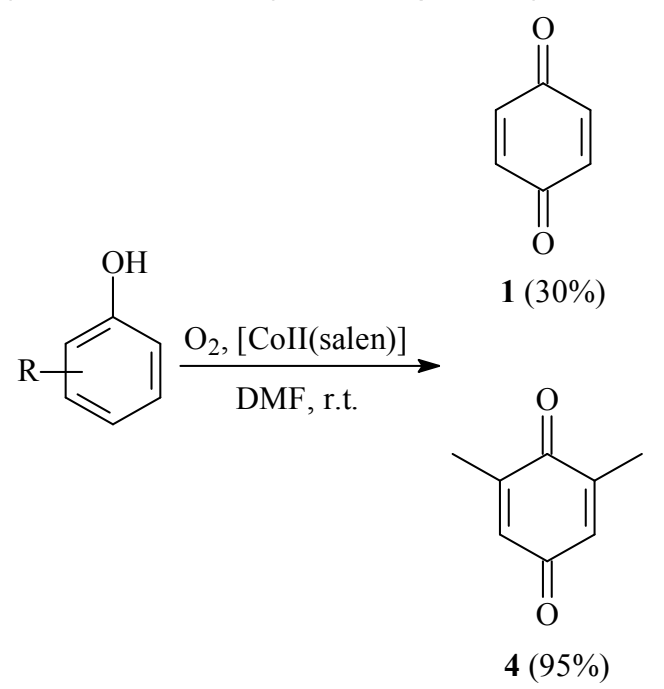

$\mathrm{mg} / \mathrm{kg}$ ), respectively, $30 \mathrm{~min}$ prior to the injection of formalin $[8,9]$.

\section{Statistical analysis}

Statistical analysis was performed using analysis of variance (ANOVA), followed by Tukey's multiple comparison test. A probability level of 0.05 was regarded as significant..

\section{RESULTS}

The results in respect of the prepared quinones are shown in the Scheme 1 and Table 1. while antinociceptive activity data are presented in Figures 1 and 2.<smiles>CC1=CC(=O)C=CC1=O</smiles><smiles>CC(C)C1=CC(=O)C=CC1=O</smiles>

$2(54 \%)$

$3(34 \%)$<smiles>CC1=CC(=O)C(C)=CC1=O</smiles>

$5(90 \%)$<smiles>CC1=CC(=O)C(C(C)C)=CC1=O</smiles>

$6(93 \%)$

Scheme 1: Oxidation of mono-phenols to para-benzoquinones

\section{DISCUSSION}

Previous studies showed that Nigella sativa seeds oil and its major component, thymoquinone, have significant antinociceptive activity [4]. Assessment of this pharmacological activity with regard to para-benzoquinones using formalin test in mice was investigated in the present work. This test is a model of acute and tonic pain, being considered a more valid model for clinical pain than tests based on mechanical or thermal stimulation [8].

The first phase results from direct chemical stimulation of the nociceptive afferent fibers, mainly $C$ fibers, and the release of substance $P$ [14], and may be inhibited by centrally acting analgesics such as morphine. The second phase is a consequence of the action 
de Sousa et al

Table 1: Characterization data of prepared compounds

\begin{tabular}{|c|c|}
\hline Compound & Physical and spectral data \\
\hline 1 & $\begin{array}{l}\text { Yield: } 30 \% \text {; Mp }{ }^{\circ} \mathrm{C}: 110-114 ; \text { Lit. } \mathrm{Mp}^{\circ} \mathrm{C}: 113-115 \text { [10]; CAS 106-51-4; }{ }^{1} \mathrm{H} \mathrm{NMR}\left(\mathrm{CDCl}_{3} / \mathrm{TMS}\right) \\
\delta, \mathrm{J}(\mathrm{Hz}): 6.79(4 \mathrm{H}, \mathrm{s}) ;{ }^{13} \mathrm{C} \text { NMR }\left(\mathrm{CDCl}_{3} / \mathrm{TMS}\right) \delta: 136.6,187.2\end{array}$ \\
\hline 2 & $\begin{array}{l}\text { Yield: } 54 \% \text {; Mp }{ }^{\circ} \mathrm{C}: 65-68 ; \text { Lit. } M p{ }^{\circ} \mathrm{C}: 67-70[11] \text {; CAS 553-97-9; }{ }^{1} \mathrm{H} \text { NMR }\left(\mathrm{CDCl}_{3} / \mathrm{TMS}\right) \delta \text {, } \\
\mathrm{J}(\mathrm{Hz}): 1.90(3 \mathrm{H}, \mathrm{s}), 6.62(1 \mathrm{H}, \mathrm{s}), 6.75(1 \mathrm{H}, \mathrm{d}, J=10.1 \mathrm{~Hz}), 6.77(1 \mathrm{H}, \mathrm{d}, J=10.1 \mathrm{~Hz}) ;{ }^{13} \mathrm{C} \text { NMR } \\
(\mathrm{CDCl} / \mathrm{TMS}) \delta: 15.8,133.3,136.4,136.5,145.9,187.5,187.7\end{array}$ \\
\hline 3 & 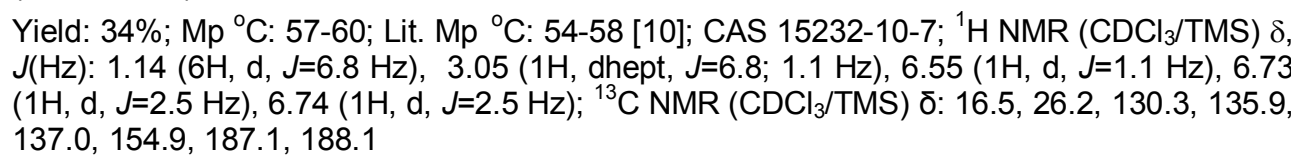 \\
\hline 4 & $\begin{array}{l}\text { Yield: } 95 \% \text {; } \mathrm{Mp}{ }^{\circ} \mathrm{C}: 69-72 ; \text { Lit. } \mathrm{Mp}{ }^{\circ} \mathrm{C}: 71-73 \text { [12]; CAS 527-61-7; }{ }^{1} \mathrm{H} \mathrm{NMR}\left(\mathrm{CDCl}_{3} / \mathrm{TMS}\right) \delta \text {, } \\
J(\mathrm{~Hz}): 2.10(6 \mathrm{H}, \mathrm{d}, \mathrm{J}=1.0 \mathrm{~Hz}), 6.56(2 \mathrm{H}, \mathrm{q}, J=1.0 \mathrm{~Hz}) ;{ }^{13} \mathrm{C} \mathrm{NMR}\left(\mathrm{CDCl}_{3} / \mathrm{TMS}\right) \delta: 15.9,133.3, \\
\text { 145.7, } 187.1\end{array}$ \\
\hline 5 & $\begin{array}{l}\text { Yield: } 90 \% \text {; Mp }{ }^{\circ} \mathrm{C}: 121-123 \text {; Lit. Mp }{ }^{\circ} \mathrm{C}: 124-125[13] ; \text { CAS 137-18-8; }{ }^{1} \mathrm{H} \mathrm{NMR}\left(\mathrm{CDCl}_{3} / \mathrm{TMS}\right) \\
\delta, J(\mathrm{~Hz}): 2.04(6 \mathrm{H}, \mathrm{d}, \mathrm{J}=1,6 \mathrm{~Hz}), 6.60(2 \mathrm{H}, \mathrm{q}, \mathrm{J}=1,6 \mathrm{~Hz}) ;{ }^{13} \mathrm{C} \text { NMR }\left(\mathrm{CDCl}_{3} / \mathrm{TMS}\right) \delta: 15.6,133.3, \\
\text { 145.7, } 188.7\end{array}$ \\
\hline 6 & 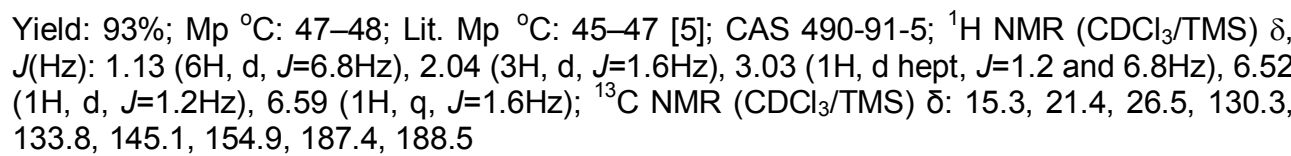 \\
\hline
\end{tabular}

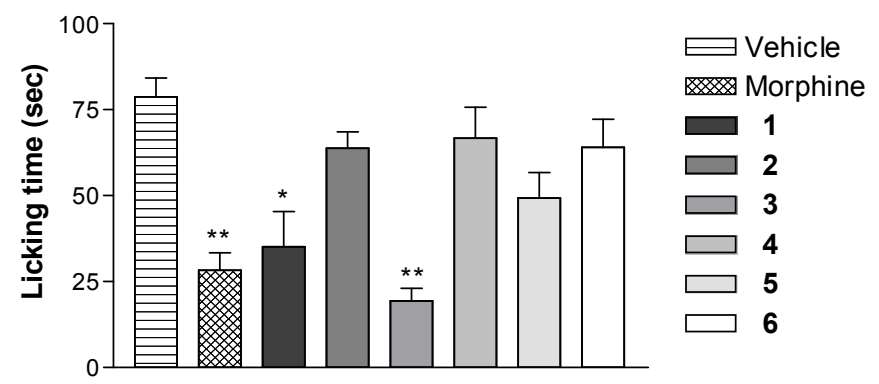

Fig 1: Effect of para-benzoquinones $1-6(10 \mathrm{mg} / \mathrm{kg}$, ip) and morphine $(10 \mathrm{mg} / \mathrm{kg}$, ip) on licking time (formalin test) during the First Phase in mice. The values represent mean \pm S.E.M. $(n=8) ;{ }^{*} p<0.01,{ }^{* *} p<$ 0.001 significantly different from control (vehicle)

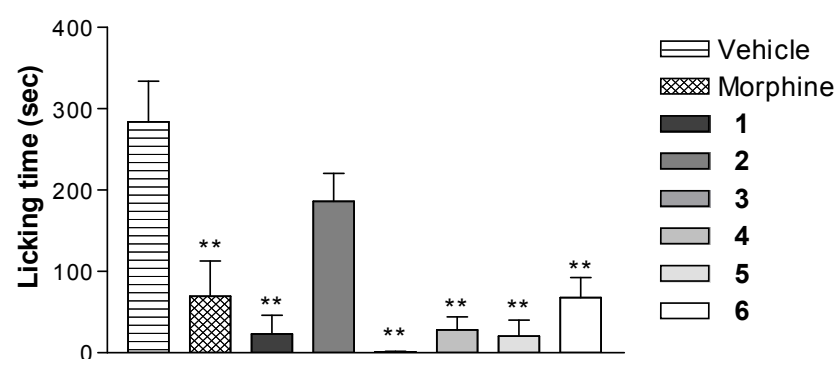

Fig 2: Effect of para-benzoquinones $1-6(10 \mathrm{mg} / \mathrm{kg}$, ip) and morphine $(10 \mathrm{mg} / \mathrm{kg}$, ip) on licking time (formalin test) during the Second Phase in mice. The values represent mean \pm S.E.M. $(n=8) ;{ }^{*} p<0.01$, ${ }^{* *} p<0.001$ significantly different from control (vehicle) 
of inflammatory mediators released locally, such as prostaglandins, serotonin, histamine, and bradykinin $[15,16]$ and also from enhanced synaptic transmission in the spinal cord [17].

Among the compounds tested, five parabenzoquinones were found to have antinociceptive activity (Figure 2). The 2isopropyl-para-benzoquinone (3) (isopropyl group at carbon 2$),(p<0.001)$, was the compound that presented the highest potency (Figure 1) and has effect in both phases. These results show that the mode of action of 3 is via central and peripheral pathways. In fact, this benzoquinone produced a near-maximal inhibition on the formalin test $(p<0.001)$, similar to morphine $(p<0.001)$ on second phase. The unsubstituted para-benzoquinone (1) (no alkyl groups) exhibited a similar effect to 3 , but was less potent in the first phase $(p<$ $0.01)$. The other quinones were inactive in this phase. These data demonstrate that the absence of alkyl groups or the presence of a bulky alkyl group in the structure of parabenzoquinones results in psychoactive compounds with antinociceptive activity. Interestingly, only compound 2 was inactive in the second phase. The other parabenzoquinones showed significant antinociceptive effect $(p<0.001)$. Therefore, para-benzoquinones 4,5 , and 6 are compounds that act peripherally, at a dose of $10 \mathrm{mg} / \mathrm{kg}$.

\section{CONCLUSION}

An attempt has been made in this study to understand the structural relationship between para-benzoquinones and their analgesic-like effects. The results suggest that by appropriate structural modification of para-benzoquinones, it may be possible to develop novel analgesic drugs

\section{ACKNOWLEDGEMENT}

The authors are grateful to Fundação de Amparo à Pesquisa do Estado de São Paulo,
Conselho Nacional de Desenvolvimento Científico e Tecnológico, and Coordenação de Aperfeiçoamento de Pessoal de Nível Superior for financial support.

\section{REFERENCES}

1. De Sousa, D.P. Analgesic-like Activity of Essential Oils Constituents. Molecules 2011; 16: 22332252.

2. Mohamed NH, Mahrous, AE. Chemical Constituents of Descurainia sophia L. and its Biological Activity. Rec Nat Prod 2009; 3: 58-67.

3. Dewick PM. Medicinal Natural Products. A Biosynthetic Approach, edn 2, John Wiley \& Sons Ltd, Chichester, 2001; pp 158-164.

4. Abdel-Fattah AM, Matsumoto $K$, Watanabe $H$. Antinociceptive effects of Nigella sativa oil and its major component, thymoquinone, in mice. Eur J Pharmacol 2000; 400: 89-97.

5. Dockal ER, Cass QB, Brocksom TJ, Brocksom U, Corrêa AGA. Simple and efficient synthesis of thymoquinone and methyl p-benzoquinone. Synth Commun 1985; 15: 1033-1036.

6. Uliana MP, Vieira YW, Donatoni MC, Corrêa AG, Brocksom U, Brocksom TJ. Oxidation of mono-phenols to para-benzoquinones: a comparative study. J Braz Chem Soc 2008; 19: 1484-1489.

7. De Almeida RN, Carlini, ELA. In: De Almeida RN (Ed), Psicofarmacologia: Fundamentos Práticos, Guanabara Koogan, Rio de Janeiro, 2006; pp 62-75.

8. Wheeler-Aceto $H$, Porreca $F$, Cowan A. The rat paw formalin test: A comparison of noxious agents. Pain 1990; 40: 229-238.

9. França DS, Souza ALS, Almeida KR, Dolabella SS, Martinelli $C$, Coelho MM. B vitamins induce an antinociceptive effect in the acetic acid and formaldehyde models of nociception in mice. Eur J Pharmacol 2001; 421: 157-164.

10. Acros Organics; Catalog of Organic and Fine Chemicals, Fisher Scientific, 2007/ 2008; vol. 282, $p 1927$.

11. Saladino R, Neri V, Mincione E, Filippone P. Selective oxidation of phenol and anisole derivatives to quinones with hydrogen peroxide and polymersupported methylrhenium trioxide systems. Tetrahedron 2002; 58: 8493-8500.

12. Barton $D H R$, Finet J-P, Thomas M. Comparative oxidation of phenols with benzeneseleninic anhydride and with benzeneseleninic acid. Tetrahedron 1988; 44: 6397-6406.

13. Adam W, Herrmann WA, Lin J, Saha-Möller CR. Catalytic oxidation of phenols to p-quinones with the hydrogen peroxide and methyltrioxorhenium(VII) System. J Org Chem 1994; 59: 8281-8283.

14. Amaral JF, Silva MIG, Neto MRA, Neto PFT, Moura BA, Melo CTV, Araújo FLO, De Sousa D P, Vasconcelos PF, Vasconcelos SM, Sousa 
de Sousa et al

FCF. Antinociceptive effect of the monoterpene $R-(+)$-limonene in mice. Biol Pharm Bull 2007; 30: 1217-1220.

15. Heapy CG, Jamieson A, Russel NJW. Afferent Cfiber and A- delta fiber activity in models of inflammation. Br J Pharmacol 1987; 90: 164170.
16. Murray CW, Porreca F, Cowan A. Methodological refinements to the mouse paw formalin test. $J$ Pharmacol Toxicol Methods 1988; 20: 175186.

17.Rujjanawate C., Kanjanapothi D, Panthong A. Pharmacological effect and toxicity of alkaloids from Gelsemium elegans Benth. J Ethnopharmacol 2003; 89: 91-95. 